\title{
Climate-based Management to Reduce Nitrate Leaching from Dairies in the Suwannee River Basin ${ }^{1}$
}

Victor E. Cabrera, Norman E. Breuer, Peter E. Hildebrand, and Clyde Fraisse ${ }^{2}$

\section{Background}

\subsection{Dairies and Nitrates}

Florida is the leading dairy state in the Southeast. It ranks $16^{\text {th }}$ nationally in cash receipts for milk, $17^{\text {th }}$ in milk production and $16^{\text {th }}$ in number of cows (Florida Agricultural Statistics Service, 2004; http://www.nass.usda.gov/f1/rtoc01.htm). Milk and cattle sales from dairies contributed $\$ 330$ million directly into the Floridian economy in 2003.

Dairy farmers in the Suwannee River Basin are aware that environmental issues will be among the greatest challenges they face in the near future. Dairy waste is thought to be an important factor contributing to nitrogen pollution in local waters. Dairy farmers are now required to comply with stricter environmental regulations, either under permit or under voluntary incentive-based programs. Dairies face increased regulation because of social pressure, while larger herds attract the attention of neighbors and activists concerned with odors, flies, and especially, potential leaching of nutrients that might influence water quality (Giesy et al., 2003).
The Suwannee River Partnership

( http://www.srwmd.state.fl.us/features/ suwannee+river+partnership/default $1 . h t m$ ) states that over the last 15 years, nitrate levels in the middle Suwannee River Basin have been on the increase, and these elevated nitrate levels can cause health problems in humans as well as negative impacts on water quality. Evidence indicates that farms may reduce their total nitrogen loads by changing some of their management practices. Improvements in long-term seasonal climate predictions ( 6 to 12 months) such as those based on El Niño and La Niña forecasts, can play an important role in implementing management strategies that dairy farmers in north Florida may adopt in order to pursue economic and ecological sustainability.

\subsection{Seasonal Climate Variation}

Climatic conditions determined by factors such as rainfall, temperature, and solar radiation are variable and uncertain. Dairy operations are affected by changes in climatic components at many different levels and in many different ways. Rainfall patterns result in different amounts of nutrient leaching. For

1. This document is IFAS Circular 1464, one of a series of the Agricultural and Biological Engineering Department, Florida Cooperative Extension Service, Institute of Food and Sciences, University of Florida. Published January 2005. Please visit the EDIS Web site at http://edis.ifas.ufl.edu.

2. Victor E. Cabrera and Norman E. Breuer, Rosentiel School of Marine and Atmospheric Science, University of Miami; Peter E. Hildebrand, Professor Emeritus, Food and Resource Economics Department, and Clyde Fraisse, Assistant Extension Scientist, Agricultural and BIological Engineering Department, University of Florida.

The Institute of Food and Agricultural Sciences (IFAS) is an Equal Opportunity Institution authorized to provide research, educational information and other services only to individuals and institutions that function with non-discrimination with respect to race, creed, color, religion, age, disability, sex, sexual orientation, marital status, national origin, political opinions or affiliations. U.S. Department of Agriculture, Cooperative Extension Service, University of Florida, IFAS, Florida A. \& M. University Cooperative Extension Program, and Boards of County Commissioners Cooperating. Larry Arrington, Dean 
example, higher temperature in winter can promote more biomass accumulation, and increase nitrogen uptake by plants, and thus reduce leaching.

Currently, knowledge of El Niño Southern Oscillation (ENSO) is being used to produce seasonal climate forecasts with a relatively high degree of skill. The ENSO signal in Florida has been well documented in terms of its effects on climatic variables (Jones et al., 2000). Precipitation in Florida is particularly variable, with an excess of over $30 \%$ of the normal seasonal total across much of the state during an El Niño winter. La Niña has the opposite effect, with deficits of $10 \%$ to $30 \%$ lasting from fall through winter and spring. Florida and the Gulf Coast can expect to see average temperatures 2 to $3^{\circ} \mathrm{C}$ below normal during El Niño years. La Niña has the opposite effect, with temperatures 2 to $4^{\circ} \mathrm{C}$ above normal during winter months. La Niña's effect on temperature is more pronounced in north Florida, Alabama, and Mississippi. Solar radiation decreases in association with higher rainfall during El Niño years. Improved and timely information (improved skill forecast) can be used to decrease environmental impacts, while maintaining profitability in north Florida dairy operations.

\subsection{Crop Rotations}

Local studies have found substantial differences in nitrogen uptake (utilization by plants) and nitrogen leaching (losses below plant roots) among crop rotations. These differences are conditioned by climate, soils, and manure nitrogen applications. For example, Woodard et al. (2002) performed an extensive experiment for four years (1996-2000) on a north Florida dairy with distinct forage systems under different rates of effluent application. They found lower rates of nitrogen leaching for bermudagrass and bermudagrass sod-planted systems, higher nitrogen leaching rates for winter forages, and medium rates for corn and sorghum in spring and summer seasons.

\section{Materials and Methods}

\subsection{The Study Area}

About 42,000 cows on some 65 dairy farms are located in the Suwannee River Basin. Most of them are in four counties in north Florida that border the Suwannee River: Gilchrist, Lafayette, Suwannee, and Levy (Bisoondat et al., 2002).

This study was performed within the Suwannee River Water Management District, which encompasses all or part of 15 counties in north central Florida (21.30 to $30.37 \mathrm{~N}$, and 82.43 to $83.35 \mathrm{~W}$ ) (For complete details of this study, see Cabrera 2004.) The study was centered in five counties where nitrogen pollution is more problematic: Alachua, Levy, Gilchrist, Lafayette, and Suwannee. The most common forages in these systems were simulated under different soils conditions, over a period of 43 years (1956-1998), and with a wide range of manure nitrogen application rates. Simulations were accomplished by using crop simulation models contained in the Decision Support Systems for Agricultural Transfer, DSSAT v.4.0 ® Software (Jones et al., 2003).

A sample of 21 dairy farms (30\% of the population) participated in the research process. This sample was obtained in cooperation with the Suwannee Partnership and the University of Florida Extension offices in the study area. The sample was intended to cover all the variability in north Florida dairy farm systems.

\subsection{Forage Crop Systems}

Part of the study was devoted to identification and understanding of forage systems used in north Florida dairy farms, including fodder plans, management practices, and sequences. Then, these crops were calibrated and validated using the DSSAT v4.0.

\subsection{Dairy Farms and Their Soils}

The study included the 10 different soil types found in the dairy systems in the Suwannee River basin. Table 1 presents these soils and their main characteristics. 


\subsection{Climate Information and El Niño Southern Oscillation (ENSO) Phases}

Between the years 1956 and 1998 (Mavromatis et al., 2002), 11 years were classified as El Niño years, 10 as La Niña years and 23 as neutral years. Each, El Niño, La Niña, or neutral year is defined as beginning in October and running through September of the next calendar year according to the Japan Meteorological Index (JMI) of sea surface temperature (OBrien et al., 1999). For example, the 1999 climate year runs form October 1998 to September 1999. In order to represent the study area, daily weather information for these years was selected from Levy County (29.42 N, $82.82 \mathrm{~W})$, located in the central south part of the Suwannee River Basin.

Figure 1 shows these values for rainfall, temperature, and solar radiation as an indication of the weather information used for the simulation with the DSSAT v4.0 crop models.

\subsection{Manure Nitrogen Application}

Dairy farm fields receive a highly variable amount of manure nitrogen depending on herd size, available land, waste management system, and overall management. The development and staging from the cows was simulated dynamically by integrating information collected in the survey with real data on seasonality, culling rates, reproduction rates, and milk production of north Florida dairies, collected by the Dairy Herd Improvement Association (FL-DHIA) and summarized by de Vries (2004). Application rates of manure nitrogen varied between 20 and $160 \mathrm{~kg} / \mathrm{ha} / \mathrm{month}$. Considering that sprayfields usually have two applications per month, four treatments were arranged with 10, 20, 40, and 80 $\mathrm{kg} / \mathrm{ha} /$ application in the DSSAT v4.0 system.

\subsection{Crop Simulations}

Forage crop simulations were performed using adapted crop models in the DSSAT v4.0 (Jones et al., 2003). These crop models are dynamic process models that simulate crop growth and yield in response to management, climate, and soil conditions. They include light interception, photosynthesis, nitrogen uptake, soil water balance, evapotranspiration, respiration, leaf area extension, growth of above ground component parts, root
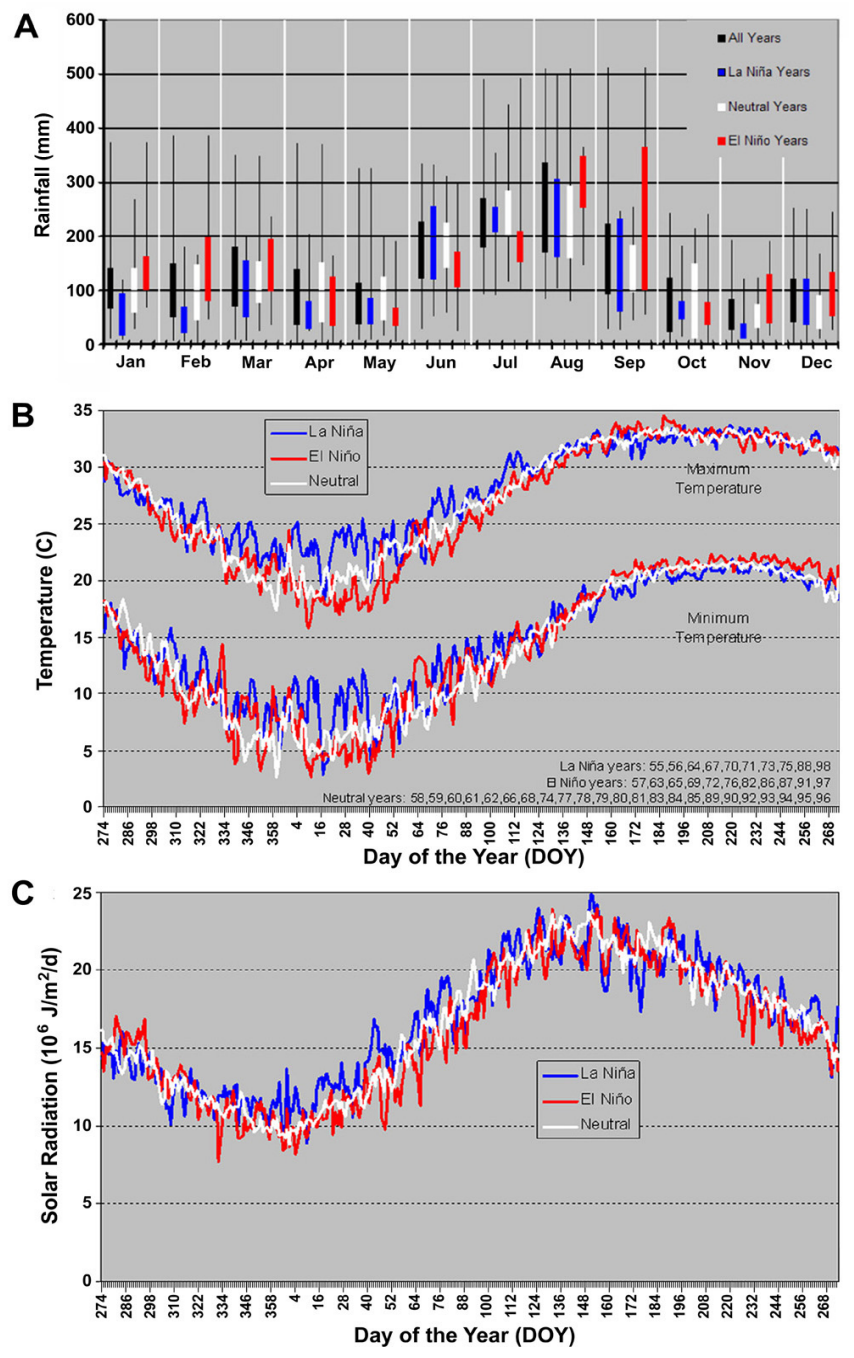

Figure 1. Climate patterns (1956-1998) in the Suwannee River Basin for different ENSO phases. A) Distribution of monthly precipitation (1956-1998). B) Daily temperature. C) Daily solar radiation.

growth, senescence, nitrogen mobilization, and crop development processes. For the soil carbon and nitrogen components, the Century model (Parton et al., 1979) implemented in the DSSAT by Gijsman et al. (2002) was used. This model estimates soil nitrogen balances that include soil and surface organic matter, inorganic nitrogen, additions and removals of nitrogen, and all the processes included in the nitrogen cycle in the soil, such as decomposition, mineralization, and nitrogen leaching.

Bahiagrass and bermudagrass (Rymph and Boote, 2004) are the only forage crops developed for the DSSAT system, therefore, part of the study consisted in adapting, calibrating, and validating crop models based on the closest existing models. For corn 
forage, maize was utilized; for forage sorghum, grain sorghum; for pearl millet, grain millet; and for winter forage small grains, wheat. These models were utilized after altering their cultivar coefficients. Calibration and validation against local, actual and current studies followed as well as a sensitivity analysis of the nitrogen leaching.

Forage systems were arranged to mimic dairy farm systems in three growing seasons: spring-summer, summer-fall, and winter. All potential forage combinations were run for four $\mathrm{N}$ effluent ranges, the 10 types of soils found in the study area, and for the 43 years of daily weather data (1956-1998).

Daily cumulative leached nitrogen and biomass $(\mathrm{kg} / \mathrm{ha})$ outputs from the simulations were compiled monthly for the span of the study period (1956-1998). All months were classified according to ENSO phases and results were summarized by the factors incorporated in the simulations: 12 months $\mathrm{x} 3$ ENSO phases x 4 Manure nitrogen applications x 10 soil types x 11 forage combinations.

\section{Results and Discussion}

\subsection{Forage Crop Systems in North Florida Dairies}

There are 3 marked seasons in the north Florida forage calendar: Spring-summer -- from late March or early April to mid July; summer-fall -- from late July or early August to early or mid November; and fall-winter -- from late November or early December to mid March (Figure 2).

Corn, bermudagrass, and bahiagrass are common crops in spring-summer. Sorghum or pearl millet could also be an option in this season, but were not reported during the interviews. Corn is planted for silage and always as a part of a sequence of crops. Bermudagrass and bahiagrass are used for hay, haylage, or grazing and they are also usually part of a sequence of crops. It is possible to over-plant bermudagrass or bahiagrass with corn in this season. One to three cuttings are expected for the grasses during this season (two are usual), if they are not grazed.

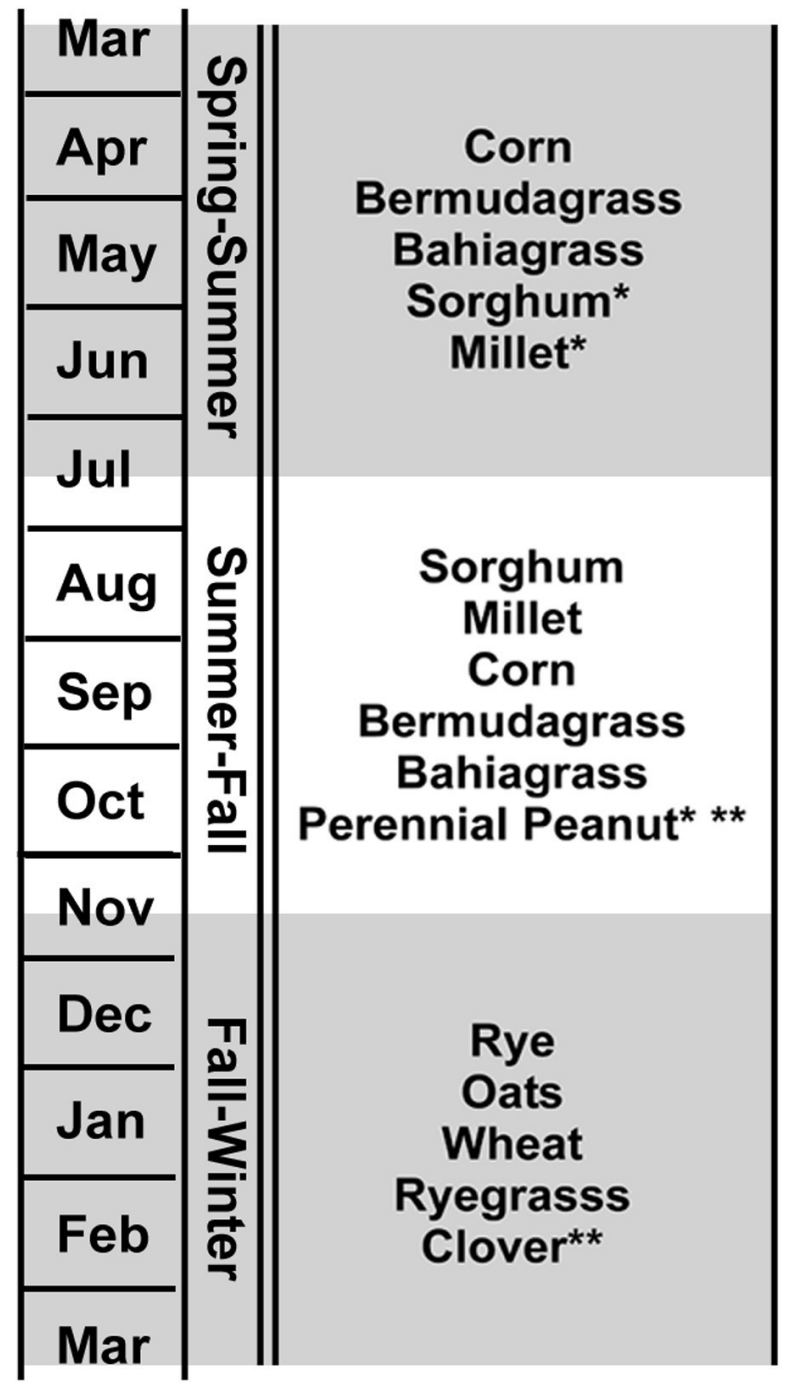

Figure 2. Forage systems and their seasonality in north-Florida dairy farms. ( ${ }^{*}$ Not found in the interviews, but they are possible. ${ }^{* *}$ Not common and not simulated with DSSAT.)

More growing options exist during summer-fall. Sorghum and millet are very common, although continuation of grasses from the previous season is also common. Some farmers also grow corn for silage in this season or let the bermudagrass or bahiagrass re-grow, if they were over-planted in spring-summer. Another option (not common) is to re-grow perennial peanut forage during this season. Sorghum, millet, perennial peanut, and the grasses can be used either for hay or haylage or for grazing. One to three cuttings will be expected for the grasses and one to two cuttings for the sorghum and millet, if they are not grazed. 
Winter forages common in the crop sequences of dairy farms in north Florida are usually small grains or ryegrass. Small grains often used are rye, oats or wheat. Although bermudagrass and bahiagrass are perennial, they are dormant during this season when they can be over-seeded or multi-cropped with other species. If there are perennial grasses already established in the field, these winter crops are usually no-till over seeded. Small grains are used for hay or haylage, ryegrass is preferred for silage. Winter small grains could be cut 1 to 4 times ( 2 cuts are usual), if they are not grazed. Clover (Trifolium spp.) was also mentioned as an option intercropped with other winter forages.

If bermudagrass or bahiagrass is established and allowed to re-grow in the spring-summer, they will continue growing in the summer-fall season, and no other crops will be possible on the same field until the fall-winter season. However, if corn is grown in spring-summer over-planted on one of those grasses, the grass will be allowed to re-grow in the summer-fall season. If corn, sorghum, or millet is planted in spring-summer, any summer-fall crop (from Figure 2 can follow. In fall-winter any small grain or ryegrass could follow any summer-fall crop.

If perennial grasses are not established, the most common sequence of forages is silage corn in spring-summer followed by sorghum or millet in the summer-fall, and any small grain or ryegrass in the fall-winter. If grasses are established, a very common sequence is grass-grass-small grain or ryegrass, for the same seasons. Bermudagrass is much more common than bahiagrass and they both are much more common than perennial peanut. Rye, oats, and wheat are very similar forages and farmers use them indistinctly. Ryegrass was indicated as having better-quality forage, but requires more care and time. It is very common to mix these winter forages in the fields. Farmers try to have a crop in the field at all times, with brief windows between the growing seasons. Regulatory agencies strongly recommend this practice in order to ameliorate the risk of $\mathrm{N}$ leaching.

With the exception of corn, all other forages have the option of being grazed directly by the animals. All forages can be cut and processed as hay, haylage, or silage. Any forage could follow any of these processes after cutting, but corn and ryegrass are highly valued for silage and the bermudagrass and bahiagrass are usually intended for hay.

\subsection{Nitrogen Leaching and ENSO Phases}

Nitrogen leaching predicted for El Niño years was substantially higher -- on the order of 10 percent higher -- than for La Niña years (357.25 and 322.29 $\mathrm{kg} / \mathrm{ha} /$ year, respectively). For neutral years, expected nitrogen leaching was $342.90 \mathrm{~kg} / \mathrm{ha} / \mathrm{year}$, intermediate between La Niña and El Niño values and very close to the overall average of 341.84 $\mathrm{kg} / \mathrm{ha} /$ year (see Table 2). Winter months, especially January and February, are critical because the nitrogen leached in these months represents more than $50 \%$ of the total nitrogen leached in a year. Substantially higher nitrogen leaching was predicted in January for El Niño years $(127.35 \mathrm{~kg} / \mathrm{ha})$ compared to either neutral $(108.90 \mathrm{~kg} / \mathrm{ha})$ or La Niña years $(83.19 \mathrm{~kg} / \mathrm{ha})$. Substantial differences were also predicted when comparing La Niña with neutral years in this month. For February, more nitrogen leaching was expected for La Niña years $(84.22$ $\mathrm{kg} / \mathrm{ha}$ ) than El Niño years $(71.60 \mathrm{~kg} / \mathrm{ha})$. Additional differences among ENSO years and different months can be observed in Figure 3.

The El Niño phase presented more overall variability through the year and maximum nitrogen leaching in the months of December, January, August, September, and November. The neutral phase presented maximum nitrogen leaching amounts during April, May, June, and October. For La Niña phases, more nitrogen leaching was expected in February, March, and July (see Table 2).

As suspected, nitrogen leaching was closely correlated to precipitation associated with climatic ENSO phases; however, it was affected by both the total amount of rainfall and the occurrence of extreme rainfall events.

\subsection{Nitrogen Leaching and Crop Systems}

Overall nitrogen leaching in an entire year varied from $281 \mathrm{~kg} / \mathrm{ha}$, when the rotation was bermudagrass-bermudagrass-winter forage, to 397 $\mathrm{kg} / \mathrm{ha}$, when the sequence was sorghum-millet-winter 

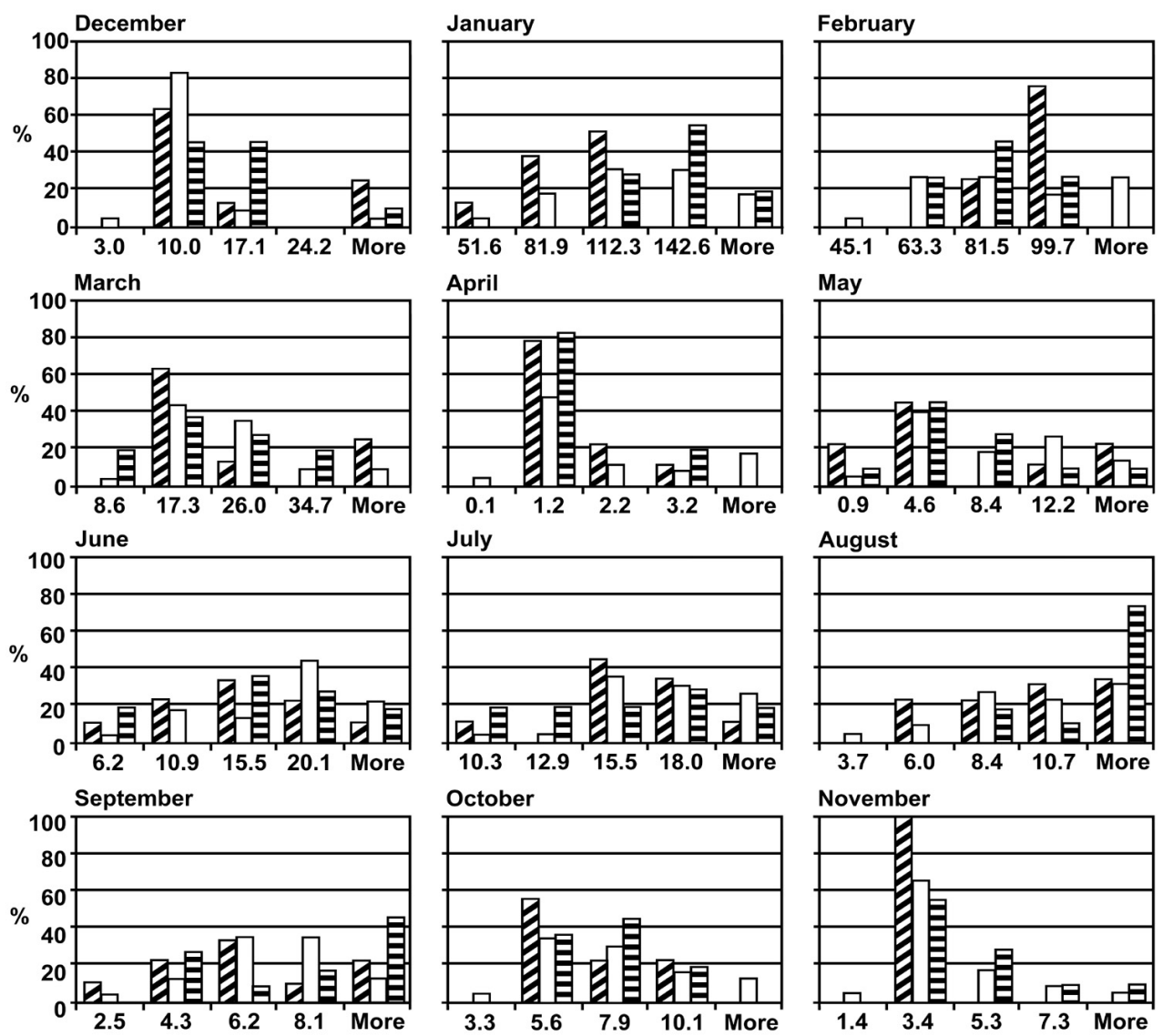

Figure 3. Frequency distribution of nitrogen leaching $(\mathrm{kg} / \mathrm{ha})$ and month of the year by ENSO phase, when all other factors are averaged. In the diagram, Neutral years are represented by bars with diagonal lines, La Niña years by blank bars, and El Niño years by bars with horizontal lines.

forage. Nitrogen leaching was predicted to be low when the rotation starts in spring with bermudagrass or corn, followed in the summer by bermudagrass, corn or bahiagrass. It was medium if it started with bahiagrass or corn followed by either bahiagrass, sorghum or millet; and it was high if the sequence started with millet or sorghum and continued with corn, sorghum, or millet (Figure 4).

\subsection{Nitrogen Leaching and Soil Types}

There was substantial variation in overall yearly nitrogen leaching for the different soil types found in north Florida. It ranged from $272 \mathrm{~kg} / \mathrm{ha} /$ year for soils type 2 to $480 \mathrm{~kg} / \mathrm{ha} /$ year for soils type 6 (see Figure 5). This fact can be mostly attributed to drainage, which is lowest for soil 2 and highest for soil 6 (Table 1). Exploring nitrogen leaching and soils more in depth shows that more nitrogen leaching occurred on those soils with lower cation exchange capacity and/or in those with higher $\mathrm{pH}$. This would be expected comparing soils with the same drainage rate (soils 1, 5, 7 and 10 with 0.75 drainage and soils 3, 4, and 9 with drainage 0.80 ; see Table 1 ).

The months with the lowest rates of nitrogen leaching, December and April, are those with the maximum variability. As in previous discussions, January and February presented the highest rates of nitrogen leaching independently of the soil type.

\section{Conclusions}

Higher nitrogen leaching (and lower biomass accumulation) is predicted for El Niño years than neutral years or La Niña years, attributed mostly to the number and intensity of rainfall events. Winter in general, and specifically January and February are the critical months for nitrogen leaching when more than $50 \%$ of annual nitrogen leaching is predicted. This is the time of lowest biomass accumulation. Biomass accumulation is the highest for corn, millet, and 


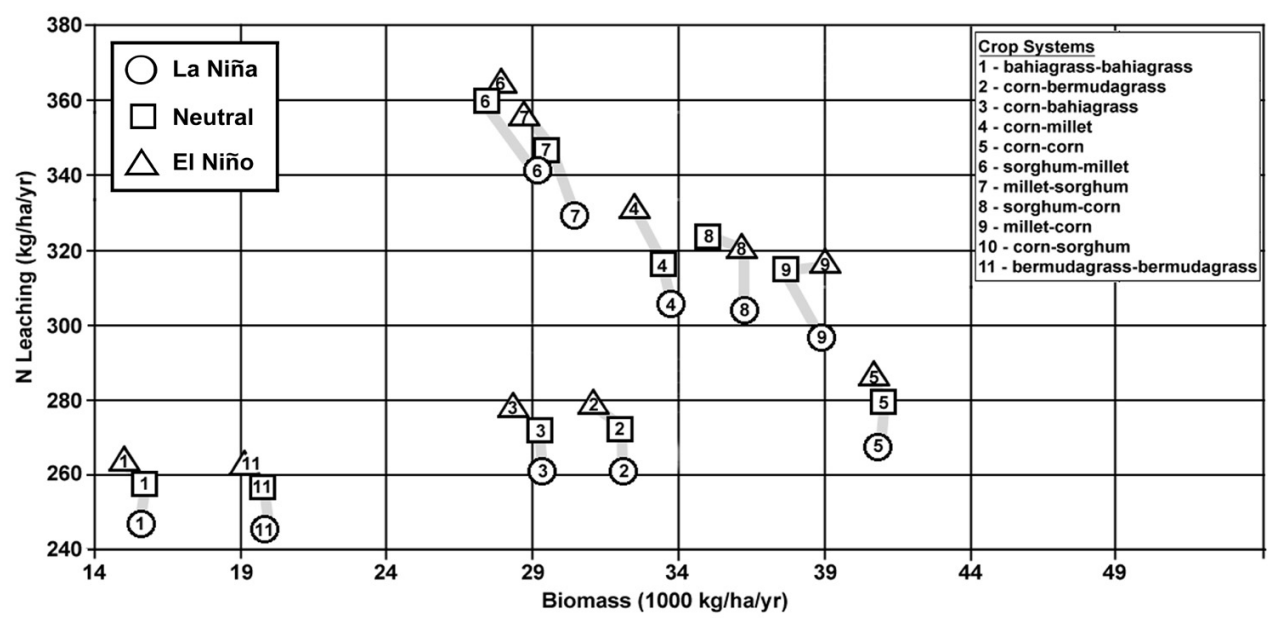

Figure 4. Nitrogen leaching vs. biomass accumulation for different forage systems under different ENSO phases (La Niña, Neutral, and EI Niño), manure $\mathrm{N}$ application of $40 \mathrm{~kg} / \mathrm{ha} / \mathrm{mo}$, and soils of type PenneyKershaw.
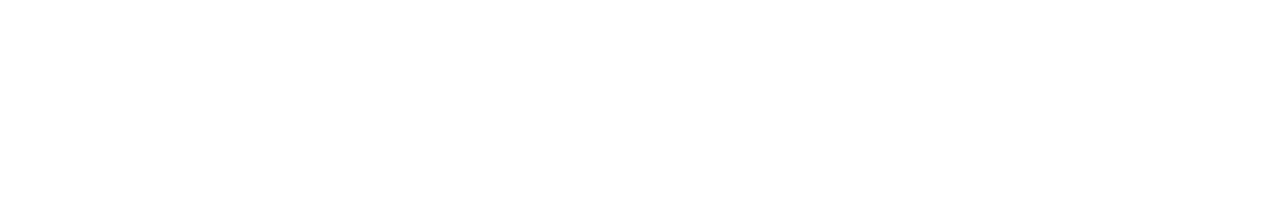

Figure 5. Nitrogen leaching vs. biomass accumulation for different soil types under different ENSO phases (La Niña, Neutral, and EI Niño), $40 \mathrm{~kg} \mathrm{ha}^{1} \mathrm{mo}^{1}$ manure $\mathrm{N}$ application $\left(40 \mathrm{~kg} \mathrm{ha}^{1} \mathrm{mo}^{1}\right)$, and forage system consisting of cornsorghumwinter forage. Note soil numbers refer to soil types defined in Table 1.

sorghum, followed by bermudagrass and bahiagrass. However, higher stability and consequently less variability is noticed in the systems when they include either of the perennials (bermudagrass or bahiagrass). The best forage systems to prevent nitrogen leaching are those that start in spring-summer with bermudagrass or corn; have bermudagrass, bahiagrass or corn in summer; and finish with winter forages. The systems that leach the most are those that include millet and/or sorghum.

There is great variability of nitrogen leaching and biomass accumulation among soil types and months of the year. Water holding capacity, $\mathrm{pH}$ and permeability of soils are believed to be the causes for these differences. Soils with very low permeability and higher $\mathrm{pH}$ facilitate the leaching of $\mathrm{N}$, and at the same time, result in higher biomass accumulation.

\section{References}

Bisoondat, M., Woodard, K.R., Sollenberger, L.E., French, E.C., Portier, K.M., Graetz, D.A., Prine, G.M., Van Horn, H.H. 2002. Dairy effluent effects on herbage yield and nutritive value of forage cropping systems. Agron. J. 94, 043-1049. 
Cabrera, V.E. 2004. Modeling north Florida dairy farm strategies to alleviate ecological impacts under varying climatic conditions: an interdisciplinary approach. Ph.D. Thesis. University of Florida. Gainesville, FL. (Available on the Internet at

〈http://etd.fcla.edu/UF/UFE0005581/cabrera_v.pdf>.

de Vries, A. 2004. Economic value of delayed replacement when cow performance is seasonal. J. Dairy Sci. 87, 2947-2958.

Giesy, R., de Vries, A., Zylstra, M., Kilmer, R., Bray, D., Webb, D. 2003. Florida dairy farm situation and outlook 2003. Coop. Ext. Serv. Circ. AN 138, Univ. Florida. Gainesville, FL.

Gijsman, A.J., Hoogenbomm, G., Parton, W.J., Kerridge, P.C. 2002. Modifying DSSAT crop models for low-input agricultural systems using soil organic matter-residue module from CENTURY. Agron. J. 94, 462-474.

Jones, J.W., Hoogenboom, G., Porter, C.H., Boote, K.J., Batchelor, W.D., Hunt. L.A., Wilkens, P.W., Singh, U., Gijsman, A.J., Ritchie, J.T. 2003. The DSSAT cropping system model. Eur. J. Agron. $18,235-265$.

Jones J.W., Hansen, J.W., Royce, F.S., Messina, C.D. 2000. Potential benefits of climate forecasting to agriculture. Agr. Ecosyst. Environ. 82, 169-184.

Mavromatis, T., Jagtap, S.S., Jones, J.W. 2002. El Niño-Southern Oscillation effects on peanut yield and $\mathrm{N}$ leaching. Climate Res. 22, 129-140.

O'Brien, J.J., Zierden, D.F., Legler, D., Hansen, J.W., Jones, J.W., Smajstrla, A.G., Podestá, G., Letson, D. 1999. El Niño, La Niña and Floridas Climate: Effects on Agriculture and Forestry. The Florida Consortium: The Florida State Univ., the Univ. of Florida, University of Miami. Tallahassee, FL.

Parton, W.J., Schimel, D.S., Cole, C.V., Ojima, D.S., 1979. Analysis of factors controlling soil organic matter levels in Great Plains grasslands. Soil Sci. Soc. Am. J. 51, 1173-1179.
Rymph, S., Boote, K.J. 2004. Modifying the Code of CropGro to Predict Growth of a Perennial Tropical Forage Grass. p. 66-67. In Proc. Biological Systems Simulation Conference, Gainesville, FL. 8-10 March 2004. University of Florida, IFAS, Gainesville, FL.

Woodard, K.R., French, E.C., Sweat, L.A., Graetz, D.A., Sollenberger, L.E., Macoon, B., Portier, K. M., Wade, B.L., Rymph, S.J., Prine, G.M., Van Horn, H.H. 2002. N removal and nitrate leaching for forage systems receiving dairy effluent. J. Environ. Qual. 31, 1980-1992. 
Table 1. Soil types, some characteristics, and their sources of information used for the study

\begin{tabular}{|c|c|c|c|c|c|c|}
\hline & \multirow[t]{2}{*}{ Series } & \multirow[t]{2}{*}{ County } & Drainage $^{1}$ & $\mathrm{CEC}^{2}$ & \multirow[t]{2}{*}{$\mathrm{pH}^{3}$} & \multirow[t]{2}{*}{ Survey } \\
\hline Type & & & Rate & $\begin{array}{c}\operatorname{meq} 100 \\
g^{-1}\end{array}$ & & \\
\hline 1 & $\begin{array}{c}\text { Arredondo-Gainesville- } \\
\text { Millhopper }\end{array}$ & Alachua & 0.75 & 6.0 & 5.9 & $\begin{array}{c}\text { Thomas et al., } \\
1985 \\
\end{array}$ \\
\hline 2 & $\begin{array}{c}\text { Arredondo-Jonesville- } \\
\text { Lake }\end{array}$ & Alachua & 0.65 & 5.0 & 6.3 & $\begin{array}{c}\text { Thomas et al., } \\
1985 \\
\end{array}$ \\
\hline 3 & $\begin{array}{c}\text { Bonneau-Blanton- } \\
\text { Eunola } \\
\end{array}$ & Gilchrist & 0.80 & 6.6 & 5.6 & $\begin{array}{c}\text { Weatherspoon et al., } \\
1992 \\
\end{array}$ \\
\hline 4 & Penney-Otela & $\begin{array}{l}\text { Gilchrist, } \\
\text { Lafayette }\end{array}$ & 0.80 & 3.6 & 4.9 & $\begin{array}{c}\text { Weatherspoon et al., } \\
1992 \\
\end{array}$ \\
\hline 5 & Penney-Kershaw & Gilchrist & 0.75 & 3.2 & 4.7 & $\begin{array}{c}\text { Weatherspoon et al., } \\
1992 \\
\end{array}$ \\
\hline 6 & Millhopper-Bonneau & Levy & 0.85 & 7.0 & 5.0 & $\begin{array}{c}\text { Slabaugh et al., } \\
1996 \\
\end{array}$ \\
\hline 7 & $\begin{array}{c}\text { Otela-Jonesville- } \\
\text { Seaboard }\end{array}$ & Levy & 0.75 & 5.5 & 5.3 & $\begin{array}{c}\text { Slabaugh et al., } \\
1996 \\
\end{array}$ \\
\hline 8 & Blanton(high)-Lakeland & Suwannee & 0.60 & 2.7 & 5.1 & $\begin{array}{c}\text { Houston, } \\
1965 \\
\end{array}$ \\
\hline 9 & Blanton(low) & Suwannee & 0.80 & 7.4 & 5.3 & $\begin{array}{c}\text { Houston, } \\
1965 \\
\end{array}$ \\
\hline 10 & Blanton-Ortega-Penny & Lafayette & 0.75 & 5.1 & 5.3 & $\begin{array}{c}\text { Weatherspoon et al., } \\
1998\end{array}$ \\
\hline & \multicolumn{6}{|c|}{$\begin{array}{l}\text { Note: Drainage, CEC, and pH are only for the first soil layer. }{ }^{1} 0.60 \text { (well), } 0.75 \text { (somewhat excessive), } 0.85 \\
\text { (excessive). }{ }^{2} \text { Cation Exchange Capacity }<3.0 \text { (extremely low), } 3.1 \text { (very low), } 5.1 \text { (low), } 7.1 \text { (medium). }{ }^{3}<5.0 \\
\text { (very strongly acid), } 5.1 \text { (strongly acid), } 5.6 \text { (moderately acid), } 6.1 \text { (slightly acid). }\end{array}$} \\
\hline
\end{tabular}

Table 2. Nitrogen leaching (kg/ha) and ENSO phases, when all other factors are averaged

\begin{tabular}{|c|c|c|c|c|c|c|c|c|}
\hline & \multicolumn{2}{|c|}{ All Years } & \multicolumn{2}{|c|}{ La Niña } & \multicolumn{2}{|c|}{ Neutral } & \multicolumn{2}{|c|}{ El Niño } \\
\hline & N Leach & CV & N Leach & CV & N Leach & CV & N Leach & CV \\
\hline Dec & 10.59 & $98 \%$ & 13.15 & $93 \%$ & 7.69 & $80 \%$ & 15.64 & 127 \\
\hline Jan & 108.42 & $32 \%$ & $83.19^{*}$ & $35 \%$ & $108.90^{*}$ & $30 \%$ & $127.35^{\star}$ & 21 \\
\hline Feb & 78.57 & $24 \%$ & $84.22^{*}$ & $9 \%$ & $79.94^{*}$ & $29 \%$ & $71.60^{*}$ & 20 \\
\hline Mar & 20.86 & $49 \%$ & 23.54 & $56 \%$ & 20.55 & $42 \%$ & 19.28 & 45 \\
\hline Apr & 5.81 & $97 \%$ & 4.90 & $78 \%$ & 6.42 & $71 \%$ & 5.45 & 70 \\
\hline May & 12.18 & $73 \%$ & 12.39 & $103 \%$ & 12.94 & $59 \%$ & 10.61 & 72 \\
\hline Jun & 23.22 & $43 \%$ & 22.01 & $45 \%$ & 25.13 & $38 \%$ & 20.69 & 50 \\
\hline Jul & 16.65 & $44 \%$ & 18.42 & $33 \%$ & 17.09 & $48 \%$ & 14.33 & 37 \\
\hline Aug & 17.05 & $40 \%$ & 16.99 & $40 \%$ & 15.65 & $38 \%$ & 19.71 & 36 \\
\hline Sep & 21.22 & $39 \%$ & 19.34 & $44 \%$ & 20.33 & $34 \%$ & 24.50 & 39 \\
\hline
\end{tabular}


Climate-based Management to Reduce Nitrate Leaching from Dairies in the Suwannee River....

Table 2. Nitrogen leaching $(\mathrm{kg} / \mathrm{ha})$ and ENSO phases, when all other factors are averaged

\begin{tabular}{||l|l|l|l|l|l|l|l|l||}
\hline \hline Oct & 20.27 & $33 \%$ & 19.02 & $35 \%$ & 20.79 & $36 \%$ & 20.35 & 21 \\
\hline Nov & 7.00 & $59 \%$ & 5.11 & $42 \%$ & 7.47 & $58 \%$ & 7.75 & 62 \\
\hline Year & \multicolumn{3}{|c|}{341.84} & \multicolumn{3}{|c|}{322.29} & \multicolumn{2}{|c||}{342.92} \\
\hline
\end{tabular}

